\title{
PENERAPAN MODEL PEMBELAJARAN THINK PAIR SQUARE (TPS) DENGAN MENGGUNAKAN LKS UNTUK MENINGKATKAN HASIL BELAJAR SISWA PADA MATERI SISTEM PERSAMAAN LINEAR DUA VARIABEL DI KELAS X SMA NEGERI 2 PEMATANGSIANTAR
}

\author{
Winmery Lasma Habeahan \\ AMIK D3 Medicom \\ winmeryhabeahan@gmail.com
}

\begin{abstract}
The purpose of this study was to determine whether using the TPS learning model by using LKS can improve student learning outcomes in the material system linear equation two variable in class X Senior High Public School 2 of Pematangsiantar. The type of research used is classroom action research with 2 cycles. Subjects of class X-IPA 7. On the implementation of the first cycle of action, the result of the analysis of tests of students at the moderate $(\geq 65)$ category in a classical manner were still not achived because only $52.78 \%$ of students were completed, with a grade average 65.00. After the implementation of the second cycle of action, the learning outcomes of students in the medium minimum category $(\geq 65)$ have been achived classically, namely $86.11 \%$ with an average value 73.75 . The increase in students' mathematics learning outcomes from cycle I to cycle II was $21.11 \%$. Based on the result of the above research it can be concluded that the application of the TPS learning model using LKS can improve student learning outcomes.
\end{abstract}

Keywords: Laerning Outcomes, Think Pair Square (TPS), LKS

\begin{abstract}
Abstrak. Tujuan penelitian ini adalah untuk mengetahui apakah dengan menggunakan model pembelajaran TPS dengan menggunakan LKS dapat meningkatkan hasil belajar siswa pada materi sistem persamaan linear dua variabel di kelas X SMA Negeri 2 Pematangsiantar. Jenis penelitian yang digunakan adalah penelitian tindakan kelas dengan 2 siklus. Subjek dalam penelitian ini adalah siswa kelas X-IPA 7. Pada pelaksanaan tindakan siklus I, hasil analisis tes siswa kategori minimal sedang $(\geq 65)$ secara klasikal masih belum tercapai karena hanya $52,78 \%$ siswa yang tuntas, dengan nilai rata-rata kelas 65,00 . Setelah pelaksanaan tindakan siklus II, hasil belajar siswa kategori minimal sedang $(\geq 65)$ secara klasikal telah tercapai yaitu $86,11 \%$ dengan nilai rata-rata 73,75 . Peningkatan hasil belajar matematika siswa dari siklus I ke siklus II adalah $21,11 \%$. Berdasarkan hasil penelitian di atas dapat disimpulkan bahwa penerapan model pembelajaran TPS dengan menggunakan LKS dapat meningkatkan hasil belajar siswa.
\end{abstract}

Kata Kunci: Hasil Belajar, Think Pair Square (TPS), LKS

\section{PENDAHULUAN}

Pendidikan merupakan salah satu faktor yang sangat penting bagi manusia dalam meningkatkan sumber daya manusia dan pendidikan juga dapat menciptakan manusia yang berkualitas. Kegiatan belajar mengajar merupakan kegiatan inti dalam upaya meningkatkan kualitas pendidikan. Baik buruknya suatu proses pembelajaran adalah salah satu faktor dominan dalam menentukan kualitas pendidikan.

Matematika merupakan salah satu mata pelajaran yang dipelajari oleh semua siswa dari jenjang pendidikan dasar hingga pendidikan lanjutan. Melalui pelajaran matematika diharapkan siswa semakin mampu dalam berhitung, berfikir logis, bertanggung jawab, memiliki kepribadian baik dan keterampilan menyelesaiakan masalah dalam kehidupan sehari-hari. Cornelius (Abdurrahman, 2009:253) mengungkapkan bahwa lima alasan tentang perlunya belajar matematika karena matematika merupakan (1) sarana berfikir jelas dan logis, (2) sarana untuk memecahkan masalah sehari-hari, (3) sarana mengenal pola- 
pola hubungan dan generalisasi pengelaman, (4) sarana untuk mengembangkan kreativitas, dan (5) sarana untuk meningkatkan kesadaran terhadap perkembangan budaya.

Mengingat pentingnya matematika dalam kehidupan manusia, maka kualitas pendidikan matematika hendaknya ditingkatkan seiring dengan perkembangan zaman. Namun pada kenyataannya bahwa pendidikan di Indonesia masih tergolong rendah dibandingkan negara lain terutama dalam pelajaran matematika. Hal ini ditunjukkan dari data UNESCO (http://www.topix.com/forum/world/indonesia/T360LENKQ6R3G1130), peringkat matematika Indonesia berada di deratan 34 dari 38 negara. Sejauh ini, Indonesia masih belum mampu lepas dari deretan penghuni papan bawah.

Rendahnya hasil belajar disebabkan oleh banyak faktor diantaranya adalah pelajaran matematika disajikan kurang menarik dan menyebabkan siswa merasa bosan pada saat mengikuti pembelajaran. Hal ini dikatakan oleh Firman (http://www.topix.com/forum/world/indonesia /T360LENKQ6R3G1130) mengatakan bahwa "Waktu yang dihabiskan siswa Indonesia di sekolah tidak sebanding dengan prestasi yang diraihnya. Ini artinya, ada sesuatu dengan metode pengajaran matematika di negeri ini. Akibatnya, siswa sering kali merasa bosan dan menganggap matematika sebagai pelajaran yang tidak menyenangkan. Selain itu model pembelajaran yang dilakukan guru masih kurang bervariasi dan cenderung tidak mengaktifkan siswa dalam belajar."

Saat pelajaran matematika berlangsung banyak yang menunjukkan bahwa pembelajaran masih berpusat pada guru di mana siswa masih kurang aktif dalam pembelajaran dan pada saat guru menerangkan pelajaran, sebagian siswa tidak memperhatikan dengan sungguh-sungguh dan siswa hanya sebagai penerima informasi. Apabila siswa mengalami kesulitan dalam memahami pelajaran, maka hanya satu atau dua orang siswa yang bertanya. Siswa merasa takut bertanya kepada guru. Demikian juga saat menanggapi pertanyaan yang diajukan guru, siswa tidak mau mengacungkan tangan sebagai tanda ingin menjawab walaupun ada di antara mereka yang tahu menjawab pertanyaan tersebut. Untuk meningkatkan hasil belajar matematika dibutuhkan peran aktif siswa. Keterlibatan siswa secara aktif merupakan hal yang sangat penting dalam memperoleh pemahaman tentang bahan yang dipelajari dan pada akhirnya akan mampu meningkatkan pemahaman siswa tentang pelajaran tersebut.

Salah satu model pembelajaran yang dapat membelajarkan siswa dan mendorong siswa untuk berperan aktif dalam pembelajaran adalah model pembelajaran kooperatif yang melibatkan seluruh siswa dengan memanfaatkan teman sebaya yang lebih pandai dalam pembelajaran. Jhonson \& Jhonson (Trianto, 2010:57) menyatakan bahwa: "Tujuan pokok belajar kooperatif adalah memaksimalkan belajar siswa untuk peningkatan prestasi akademik dan pemahaman baik secara individu maupun secara kelompok".

Model pembelajaran kooperatif memiliki beberapa tipe, dan diantara beberapa tipe tersebut peneliti memilih model pembelajaran kooperatif tipe Think Pair Square (TPS). Model pembelajaran kooperatif tipe Think Pair Square (TPS) merupakan model pembelajaran yang dikembangkan oleh Frank Lyman dan Spencer Kagan (Lie, 2010:57). Model ini memberikan kesempatan kepada siswa untuk saling memberikan ide-ide dan mempertimbangkan jawaban yang paling tepat. Selain itu, pembelajaran kooperatif tipe Think Pair Square (TPS) juga mendorong siswa untuk meningkatkan semangat kerjasama siswa dan dapat memudahkan pembagian tugas.

Soal-soal dan pertanyaan yang berhubungan dengan materi sistem persamaan linear dua variabel dapat disusun dalam bentuk LKS. LKS merupakan media yang digunakan dalam pembelajaran kooperatif tipe Think Pair Square (TPS). Dengan adanya LKS, dapat memudahkan guru dalam pemberian tugas baik yang berupa kegiatan maupun evaluasi. Sedangkan bagi siswa bermanfaat terutama sebagai pemandu dalam kegiatan belajar mengajar. Melalui LKS aktivitas siswa dalam belajar mengajar dapat ditingkatkan. 
Berdasarkan uraian di atas maka tujuan penelitian ini adalah untuk mengetahui apakah dengan menggunakan model pembelajaran Think Pair Square (TPS) dengan menggunakan LKS dapat meningkatkan hasil belajar siswa pada materi sistem persamaan linear dua variabel di kelas X SMA Negeri 2 Pematangsiantar

\section{METODE}

Jenis penelitian ini adalah penelitian tindakan kelas (classroom action research) yaitu penelitian tindakan (action research) yang dilakukan dengan tujuan memperbaiki pembelajaran di kelas. Karena penelitian ini bertujuan untuk meningkatkan hasil belajar matematika siswa pada materi Sistem Persamaan melalui penerapan model pembelajaran Think Pair Square (TPS).

Yang menjadi subjek penelitian dalam penelitian ini adalah siswa kelas X-IPA 7 SMA Negeri 2 Pematangsiantar yang berjumlah 36 orang. Pembelajaran dirancang dengan menggunakan penerapan model pembelajaran kooperatif tipe Think Pair Square (TPS) dilaksanakan dari yang sederhana menuju tingkat yang lebih efektif untuk memberikan hasil yang lebih optimal. Kegiatan dilaksanakan dua siklus dengan 5 pertemuan dimana siklus I terdapat tiga RPP (RPP I, RPP II, dan RPP III) dan siklus II terdapat dua RPP (RPP I dan RPP II).

Diakhir pembelajaran dilakukan tes. Setelah selesai kegiatan pembelajaran, dilakukan refleksi terhadap pelaksanaan pembelajaran dan hasil observasi. Observasi yang dilakukan untuk melihat bagaimana aktivitas siswa selama pembelajaran berlangsung dan bagaimana hasil tes diperoleh. Dari hasil refleksi siklus I guru merancang pembelajaran yang lebih efektif untuk pembelajaran selanjutnya, demikian seterusnya untuk pembelajaran berikutnya. Peneliti merencanakan siklus penelitian sebanyak dua siklus, Secara lebih rinci, prosedur pelaksanaan penelitian tindakan kelas menurut Arikunto (2010:16), dapat digambarkan sebagai berikut:

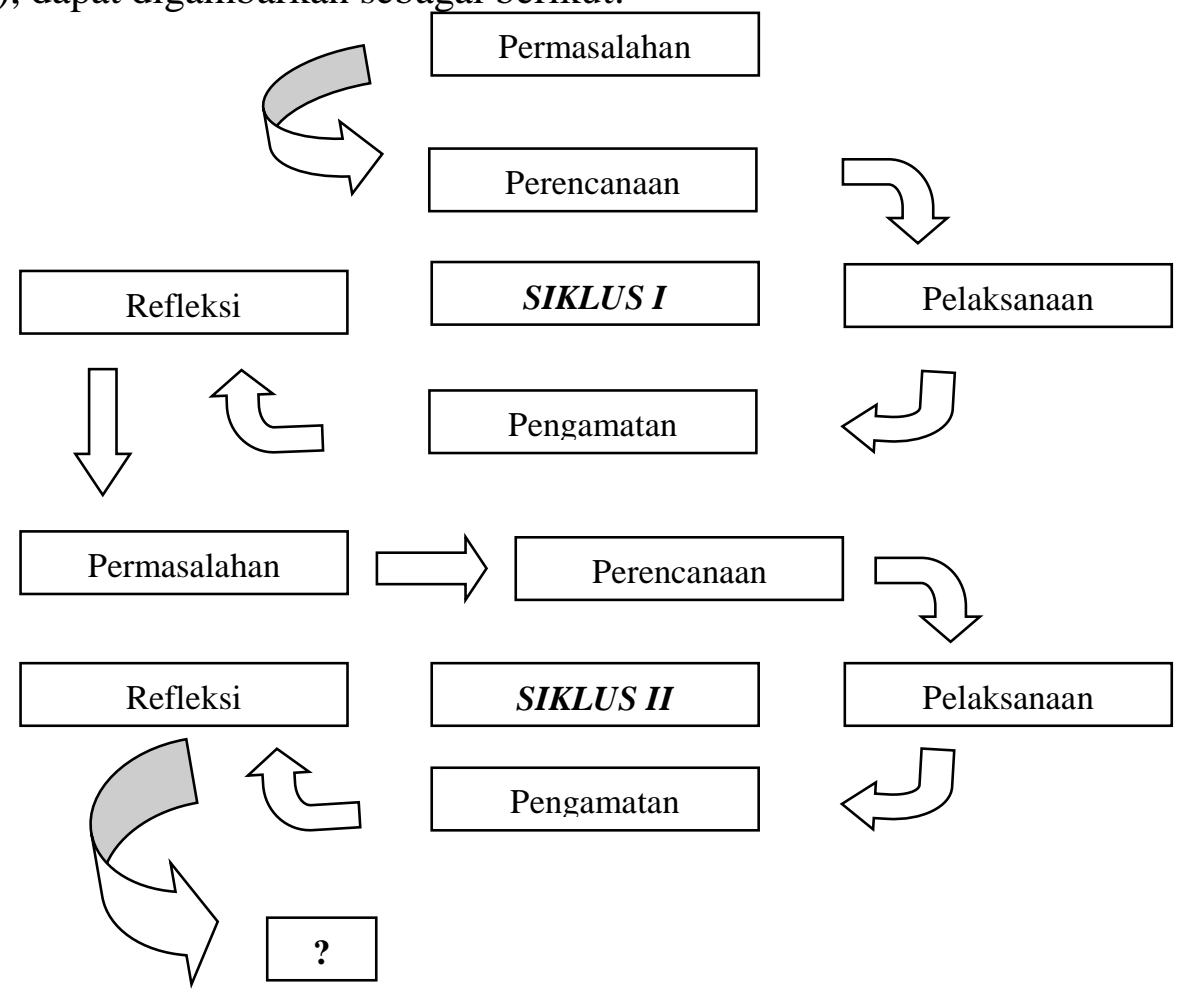

Gambar 1. Prosedur Penelitian Tindakan Kelas

Dalam penulisan ini hasil belajar siswa dikatakan meningkat apabila persentase ketuntasan individual dan ketuntasan klasikal yang diperoleh siswa semakin meningkat dari 
tes yang dilakukan pada setiap siklusnya sekurang-kurangnya $85 \%$ siswa memperoleh nilai tes $\geq 65 \%$. Siswa dikatakan mengalami kesulitan belajar berdasarkan kriteria pendidikan jika siswa tidak dapat mencapai tujuan yang ditetapkan setelah mengikuti tes, serta jika hasil prestasinya berada dibawah rata-rata siswa yang lain

\section{HASIL DAN PEMBAHASAN \\ Hasil}

Hasil belajar matematika siswa pada tes awal yaitu rataan skor ujian pre-tes siswa sebesar 38,75 akan digunakan sebagai alat evaluasi dengan membandingkannya terhadap hasil pembelajaran yang akan dilaksanakan selanjutnya. Sehubungan dengan tujuan tindakan untuk meningkatkan hasil belajar siswa maka dilakukan tes untuk siswa. Tes yang dilakukan adalah materi yang berhubungan pada RPP 1, RPP 2, dan RPP 3.

Tabel 1. Tes Hasil Belajar Siklus I

\begin{tabular}{ccccc}
\hline No & $\begin{array}{c}\text { Persentase } \\
\text { Ketuntasan }\end{array}$ & $\begin{array}{c}\text { Tingkat } \\
\text { Ketuntasan }\end{array}$ & Banyak Siswa & $\begin{array}{c}\text { Persentase } \\
\text { Jumlah Siswa }\end{array}$ \\
\hline 1 & $<$ Nilai 65 & Tidak Tuntas & 17 orang & $47,22 \%$ \\
\hline 2 & $>$ Nilai 65 & Tuntas & 19 orang & $52,78 \%$ \\
\hline Jumlah & & 36 orang & $100 \%$ \\
\hline
\end{tabular}

Pada pelaksanaan tindakan siklus I, hasil analisis tes siswa kategori minimal sedang ( $\geq 65$ ) secara klasikal masih belum tercapai karena hanya $52,78 \%$ siswa yang tuntas, dengan nilai rata-rata kelas 65,00.

Karena hasil belajar belum memenuhi syarat ketuntasan maka untuk meningkatkan hasil belajar siswa maka dilakukan tes untuk siswa pada siklus II. Tes yang dilakukan adalah materi yang berhubungan pada RPP 4 dan RPP 5. Untuk mengetahui peningkatan kemampuan siswa setelah siklus II maka dibandingkan dengan tes siklus I. Dari hasil tes yang dilakukan pada siklus kedua, siswa yang tuntas belajar 31 siswa $(86,11 \%)$, sedangkan yang tidak tuntas belajar 5 siswa $(13,89 \%)$ dengan rata-rata kelas 73,75 sehingga ketuntasan belajar klasikal sudah tercapai.

Tabel 4. Ringkasan Tingkat Ketuntasan Belajar Siswa Secara Klasikal pada Siklus II

\begin{tabular}{ccccc}
\hline No & $\begin{array}{c}\text { Persentase } \\
\text { Ketuntasan }\end{array}$ & $\begin{array}{c}\text { Tingkat } \\
\text { Ketuntasan }\end{array}$ & Banyak Siswa & $\begin{array}{c}\text { Persentase } \\
\text { Jumlah Siswa }\end{array}$ \\
\hline 1 & $<$ Nilai 65 & Tidak Tuntas & 5 orang & $13,89 \%$ \\
\hline 2 & $>$ Nilai 65 & Tuntas & 31 orang & $86,11 \%$ \\
\hline & Jumlah & & 36 orang & $100 \%$ \\
\hline
\end{tabular}

Selama pembelajaran berlangsung keaktifan siswa mengalami peningkatan. Hal ini terlihat dari data hasil observasi terhadap aktivitas siswa selama pembelajaran berlangsung dari 44,31\% (kategori kurang aktif) pada siklus pertama menjadi 71,2\% (kategori aktif) pada siklus II.

\section{Pembahasan}

Kondisi awal siswa merupakan masa penjajagan sebelum melakukan tindakan (penelitian tindakan). Penjajagan dilakukan di SMA Negeri 2 Pematangsiantar kelas X. Hasil belajar matematika siswa sebelumnya yaitu rataaan skor ujian pre-tes siswa adalah 38,75 akan digunakan sebagai alat evaluasi dengan membandingkannya terhadap hasil pembelajaran yang akan dilaksanakan selanjutnya.

Urutan rencana pelaksanaan putaran I adalah menyusun Rencana Pelaksanaan Pembelajaran (RPP) yang berisikan langkah-langkah kegiatan dalam pembelajaran yang menggunakan model pembelajaran kooperatif tipe Think Pair Square (TPS), menyusun 
soal tes hasil belajar siswa untuk mengukur kemampuan siswa dalam menyelesaikan dan memahami soal-soal sistem persamaan linear dua variable, mempersiapkan sarana pendukung pembelajaran yang mendukung pelaksanaan tindakan, yaitu: (1) lembar kerja siswa (LKS), (2) buku mata pelajaran untuk peneliti, dan membentuk kelompok diskusi yang heterogen terdiri dari 4 orang tiap kelompok berdasarkan hasil dari tes awal.

Kegiatan pembelajaran pada siklus I dilakukan sebanyak 3 kali pertemuan dan di setiap kegiatan pembelajaran dilaksanakan observasi, kepada siswa diberikan tes untuk mengukur hasil belajar siswa dan dicari rata-ratanya. Pada pelaksanaan tindakan siklus I, hasil analisis tes siswa kategori minimal sedang $(\geq 65)$ secara klasikal masih belum tercapai karena hanya 52,78\% siswa yang tuntas, dengan nilai rata-rata kelas 65,00. Sebelum melanjutkan ke siklus berikutnya dilaksanakan refleksi. Hasil dari refleksi didapat bahwa siswa yang aktif dalam kelompok masih didominasi oleh siswa yang pintar, hanya beberapa siswa yang aktif mengemukakan pendapat dan masih ada siswa yang kurang aktif saat mendiskusikan LKS, kemampuan siswa dalam menyelesaikan soal system persamaan linear dua variabel masih kurang baik hal ini dapat dilihat dari banyaknya kesalahan yang dilakukan siswa mengerjakan tes.

Putaran II ini bertujuan untuk memantapkan pemahaman dan perbaikan pelaksanaan pembelajaran dengan menggunkan model pembelajaran kooperatif tipe Think Pair Square (TPS). Adapun langkah-langkah yang ditempuh dalam rencana tindakan II sama dengan langkah pada siklus I dengan menggunakan RPP 4 dan RPP 5. Diakhir pembelajaran dilaksanakan tes yang diperoleh bahwa dari hasil tes yang dilakukan pada siklus kedua, siswa yang tuntas belajar 31 siswa $(86,11 \%)$, sedangkan yang tidak tuntas belajar 5 siswa $(13,89 \%)$ dengan rata-rata kelas 73,75 sehingga ketuntasan belajar klasikal sudah tercapai. Maka berdasarkan hal tersebut dapat disimpulkan bahwa melalui penrapan model pembelajaran Think Pair Square (TPS) dengan menggunakan LKS dapat meningkatkan hasil belajar siswa pada materi sistem persamaan linier dua variabel.

\section{KESIMPULAN}

Berdasarkan hasil dan pembahasan disimpulkan bahwa melalui penggunaan LKS dengan menggunakan model pembelajaran Think Pair Square (TPS), siswa yang tuntas belajar 31 siswa $(86,11 \%)$, sedangkan yang tidak tuntas belajar 5 siswa $(13,89 \%)$ dengan rata-rata kelas 73,75 sehingga ketuntasan belajar klasikal sudah tercapai. Maka dari hasil ini disarankan untuk peneliti selanjutnya untuk lebih mendalami model pembelajaran Think Pair Square (TPS) sehingga mampu lebih meningkatkan lagi hasil belajar siswa pada materi lainnya.

\section{DAFTAR PUSTAKA}

Abdurrahman, M. 2009. Pendidikan Bagi Anak Berkesulitan Belajar. Jakarta: Rineka Cipta Arends, R. L. 2008. Learning To Teach Belajar Untuk Mengajar. Yogyakarta: Pustaka Pelajar

Arikunto, dkk.2010.Penelitian Tindakan Kelas. Jakarta: Bumi Aksara.

Djamarah, S. B., Zain, S. 2006. Strategi Belajar Mengajar. Jakarta: Rineka Cipta

Forum Indonesia. 2007. Rendah, Prestasi Matematika Indonesia Jumlah Jam Pelajaran dan Prestasi tak Sebanding: http://www.topix.com /forum /world /indonesia/T360LENKQ6R3G1130 (diakses tanggal 15 April 2013 21:22:53 GMT)

Hamalik, O. 2010. Proses Belajar Mengajar. Bandung: Bumi Aksara

Hudojo, H. 1988. Mengajar Belajar Matematika. Jakarta: Depdikbud

Karso, dkk. 1994. Dasar-Dasar Pendidikan MIPA. Jakarta: Departemen Pendidikan dan Kebudayaan 
Komalasari, K. 2010. Pembelajaran Kontekstual Konsep dan Aplikasi. Bandung: PT. Refika Aditama

Lie, A. 2010. Cooperative Learning. Jakarta: Grasindo

Priatma, N., Sukamto, T. 2010.Mathematics Advanced Learning For Grade X Senior High School. Grafindo: Bandung

Rasyid, H. 2009. Penelitian Hasil Belajar. Bandung: CV. Wacana Prina

Rohani, A. 2010. Pengelolaan Pengajaran. Jakarta: Rineka Cipta

Sardiman, A. M. 2011. Interaksi dan Motivasi Belajar Belajar Mengajar. Jakarta: Rajawali Pers

Subino. 1987. Konstruksi dan Analisisn Tes. Jakarta: Departemen Pendidikan dan Kebudayaan

Suherman, E. 1990. Evaluasi Pendidikan Matematika. Bandung: Wijayakusuma Syah, M. 2010. Psikologi Pendidikan dengan Pendekatan Baru. Bandung: Rosda

Trianto. 2010. Mendesain Model Pembelajaran Inovatif- Progresif. Jakarta: Kencana 